\title{
PENDIDIKAN POLITIK DALAM RANGKA PENGUATAN PARTISIPASI POLITIK PEMUDA
}

\author{
Halifa Haqqi \\ email : halifahaqqi@gmail.com \\ GPH Dipokusumo \\ email : gustidipo@gmail.com
}

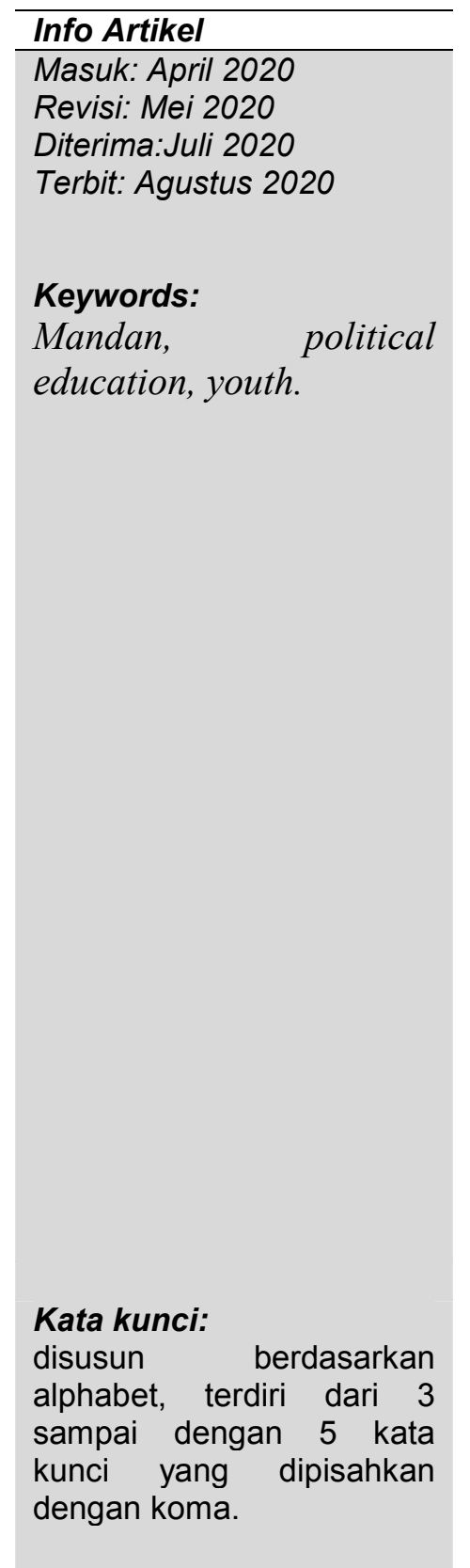

\begin{abstract}
To encourage political participation, good political education is needed. Political education can target young people as agents of change that have much influence in political development. Therefore, it is important to provide political education in strengthening the political participation of Indonesian youth. This program aims to provide Political Education in Strengthening Youth Political Participation. The service program was held in a four-month time series, from January to April 2019. The socialization activities had been held in Mandan, Sukoharjo Regency on Saturday, April 21, 2019 for one day, attended by 34 young people. The method used in program was socialization and active discussions, and providing motivation for the participants, which was previously preceded by participant assessment activities. The socialization activity lasted for one day. The core material of socialization consists of (1) political introduction; (2) the importance of political participation; (3) youth's ideal actions in political participation. The members of this program were Youth Organization of Mandan, Sukoharjo. Through this program, it can be beneficial for: (1) youth and the general public, to get a picture of political education and positive political participation; (2) for regions, can develop regional potential, regional promotion, and regional development; (3) for tertiary institutions, as fulfillment of the Tri Dharma element of Higher Education.
\end{abstract}

\footnotetext{
Abstrak

Untuk mendorong partisipasi politik, diperlukan pendidikan politik yang baik. Pendidikan politik dapat menargetkan kaum muda sebagai agen perubahan yang memiliki banyak pengaruh dalam perkembangan politik. Karena itu, penting untuk memberikan pendidikan politik dalam memperkuat partisipasi politik pemuda Indonesia. Program ini bertujuan
} 
P-ISSN: 2598-2273

E-ISSN: 2598-2281

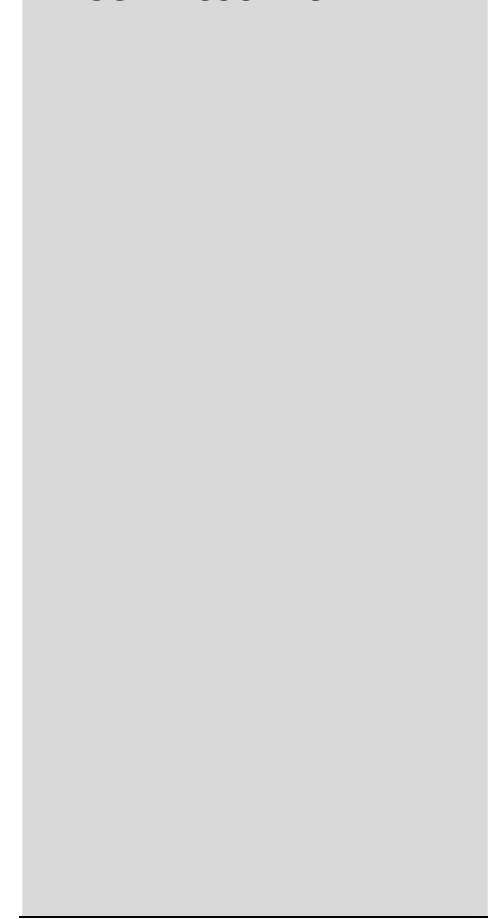

untuk memberikan Pendidikan Politik dalam Memperkuat Partisipasi Politik Pemuda. Program layanan diadakan dalam seri waktu empat bulan, dari Januari hingga April 2019. Kegiatan sosialisasi telah diadakan di Mandan, Kabupaten Sukoharjo pada hari Sabtu, 21 April 2019 selama satu hari, dihadiri oleh 34 orang muda. Metode yang digunakan dalam program ini adalah sosialisasi dan diskusi aktif, dan memberikan motivasi bagi para peserta, yang sebelumnya didahului oleh kegiatan penilaian peserta. Kegiatan sosialisasi berlangsung selama satu hari. Materi inti sosialisasi terdiri dari (1) pengenalan politik; (2) pentingnya partisipasi politik; (3) tindakan ideal pemuda dalam partisipasi politik. Anggota program ini adalah Organisasi Pemuda Mandan, Sukoharjo. Melalui program ini, dapat bermanfaat bagi: (1) pemuda dan masyarakat umum, untuk mendapatkan gambaran pendidikan politik dan partisipasi politik positif; (2) untuk daerah, dapat mengembangkan potensi daerah, promosi daerah, dan pengembangan daerah; (3) untuk perguruan tinggi, sebagai pemenuhan unsur Tri Dharma Pendidikan Tinggi.

\section{PENDAHULUAN}

Perkembangan politik di Indonesia terus bergeser ke arah proses demokratisasi. Sebagai konsekuensinya, dinamika kehidupan politik nasional ikut mengalami pergeseran. Tak hanya itu, sistem politik yang bergeser juga membawa perubahan terhadap dinamika sistem lain yang berkaitan dengan penyelenggaraan kehidupan kenegaraan. Kondisi ini menunjukkan tingkat keberhasilan pembangunan politik yang demokratis di Indonesia.

Pembangunan politik Indonesia ini dipengaruhi oleh berbagai faktor seperti situasi yang berkembang di dalam negeri, maupun konstelasi politik internasional. Namun, yang paling utama adalah bagaimana perkembangan partisipasi politik yang berlangsung dalam masyarakat. Pada negara demokrasi, partisipasi politik merupakan elemen esensial. Sebab, indikator kualitas demokrasi suatu negara banyak ditentukan oleh tinggi rendahnya partisipasi politik dari masyarakat dalam kehidupan politik yang dilakukan lewat berbagai cara.

Partisipasi politik masyarakat dapat diwujudkan dalam berbagai cara yang luas, seperti dengan ikut serta dalam memilih pimpinan negara, menghadiri rapat 
umum, mematuhi aturan politik, menjalin hubungan dengan pejabat pemerintahan, dan lain sebagainya. Berbagai partisipasi politik yang dilakukan masyarakat ini secara langsung maupun tidak langsung dapat memengaruhi kebijakan pemerintah. Untuk itulah, penting bagi suatu masyarakat negara demokrasi untuk memiliki pendidikan pendidikan politik yang cukup.

Rusadi Kantaprawira (2004:55 menyebutkan bahwa pendidikan politik berguna untuk meningkatkan pengetahuan masyarakat sehingga mereka dapat berpartisipasi dalam sistem politiknya secara maksimal. Rakyat harus mampu menjalankan tugas partisipasi politik ini dengan baik sesuai paham kedaulatan rakyat atau demokrasi. Adapun bentuk-bentuk pendidikan politik yang diberikan pada masyarakat, dapat dilakukan melalui beberapa cara, seperti : (1) Bahan bacaan seperti surat kabar, majalah, dan lain-lain bentuk publikasi massa yang biasa membentuk pendapat umum; (2) Siaran radio dan televisi serta film (audio visual media); (3) Lembaga atau asosiasi dalam masyarakat seperti masjid atau gereja tempat menyampaikan khotbah, dan juga lembaga pendidikan formal ataupun iniformal.

Pendidikan politik juga dapat dilakukan secara luas, mencakup segala kegiatan yang berkaitan dengan urusan yang terkait kepentingan dari sekelompok masyarakat (negara) sehingga mereka mengetahui hak-hak dan kewajibannya. Pendidikan politik merupakan proses yang mempengaruhi individu sehingga individu tersebut memperoleh informasi, wawasan dan ketrampilan politik. Pada akhirnya, bekal ini akan membuat dirinya sanggup berikap kritis dan lebih terarah dalam tindakan politiknya. Pendidikan politik juga berguna bagi individu agar mampu menjadi warga Negara yang lebih baik dan tidak mudah terpengaruh orientasi terhadap kepentingan pihak lain yang tidak bertanggun jawab (Prabowo, $2000: 4-5$ ).

Bagi para pemuda, pendidikan politik adalah hal penting guna meningkatkan kualitas partisipasi politik pemuda dalam mengawasi dan mengawal kegiatan perpolitikan di tanah air. Hal ini juga termasuk dalam mendorong partisipasinya dalam pemilihan umum. Melalui pendidikan politik yang tepat, para pemuda akan memiliki pengetahuan tentang dinamika politik yang berkembang secara lebih matang. 
Pemerintah selama ini telah menunjukkan upayanya untuk dapat mendorong peningkatkan partisipasi politik para pemuda yang dapat diwujudkan dalam berbagai bentuk, seperti keterlibatan dalam kegiatan organisasi, mencari koneksi politik yang ideal, menghindari tindak kekerasan (violence), dan keterlibatan dalam kegiatan pemilih (Bappenas dan Depdagri, 2002 : 25). Pada dasarnya, pendidikan dan partisipasi politik pemuda dapat turut berkembang sesuai keadaan dan kebutuhan yang tidak terbatas.

Pada politik modern, kegiatan partisipasi politik juga menjadi semakin vital untuk dipelajari. Hal ini terutama bagaimana masyarakat pemuda dapat melihat hubungan yang terjalin pada intern negara dan relasi antar negara secara internasional. Bagaimana pun juga, keterlibatan para pemuda dalam politik dapat berkontribusi terhadap kemajuan bangsa (Leungo, 2006 : 9). Pentingnya keterlibatan pemuda dalam mendukung perkembangan politik suatu negara memacu kajian mengenai bagaimana mendorong para pemuda ini agar dapat terlibat aktif dan positif dalam dunia politik.

Oleh karena itu, berlandaskan motivasi untuk mempersiapkan masa depan bangsa dan negara yang lebih baik sehingga partisipasi politik dapat berjalan dengan baik, dan menghasilkan output positif, maka program sosialisasi pendidikan politik dalam rangka penguatan partisipasi politik pemuda di Indonesia dianggap menjadi hal penting. Hal ini sebagai upaya menumbuhkan legitimasi politik di kalangan para pemuda yang merupakan penerus bangsa. Adapun program pengabdian akan dilaksanakan dengan mitra Kelurahan Mandan, Kelurahan Mandan, Kecamatan, Sukoharjo, Kabupaten Sukoharjo.

Secara terkhusus, program pengabdian akan dilakukan dengan target sasaran para pemuda yang tergabung dalam Karang Taruna Kelurahan Mandan, Kabupaten Sukoharjo. Karang Taruna Mandan termasuk kelompok pemuda yang cukup aktif mengadakan kegiatan. Namun demikian, mereka belum pernah mendapatkan pendidikan politik dari pihak mana pun. Padahal, mengingat pentingnya pendidikan politik demi meningkatkan partisipasi politik pemuda, maka para pemuda tersebut sesuai untuk menjadi sasaran program kegiatan. Berdasarkan uraian di atas, rumusan masalah yang hendak dijawab melalui kegiatan Pengabdian pada 
Masyarakat ini, berupa: "Bagaimana upaya pendidikan politik dalam rangka penguatan partisipasi politik pemuda di Indonesia?"

\section{Gambaran Kelompok Sasaran}

Kelompok sasaran program pengabdian adalah para pemuda anggota anggota Karang Taruna Kelurahan Mandan, yang berlokasi di Kecamatan Mandan, Kabupaten Sukoharjo, Jawa Tengah. Jumlah anggota Karang Taruna tersebut erdiri dari para remaja dengan rentang usia antara 14 tahun hingga 21 tahun. Kelompok tersebut sesuai dengan target sasaran program pengabdian sebagai upaya pendidikan politik dalam rangka penguatan partisipasi politik pemuda. Kelompok pemuda yang dianggap membutuhkan penguatan pendidikan politik ini adalah mereka yang memiliki keterbatasan akses terhadap aneka informasi politik dan telah atau akan segera memiliki hak politik berupa hak pilih.

Berdasarkan kriteria tersebut, dipilih kelompok sasaran program yakni para pemuda yang tergabung dalam Karang Taruna Mandan. Adapun lokasi mitra tersebut adalah di Kelurahan Mandan, Kecamatan Mandan, Kabupaten Sukoharjo, Jawa Tengah. Para pemuda dalam kelompok tersebut berusia mulai dari 14 tahun hingga 21 tahun, yang berarti akan dan telah memiliki hak politik berupa hak pilih. Selain itu, dilihat dari kondisi wilayah pedesaandan kegiatan para pemudanya, dapat dikatakan bahwa akses terhadap informasi politik masih minim.

Kondisi geografis yang berada di daerah pedesaanmempengaruhi minat para pemuda terhadap politik. Sebab, wilayah pedesaanseringkali cenderung skpetis terhadap dunia politik. Minimnya informasi, wawasan serta pendampingan politik turut berpengaruh terhadap sikap abai para pemuda terhadap dunia politik. Kondisi ini menjadi kekhawatiran tersendiri sehingga dibutuhkan pendampingan khusus, berupa sosialisasi akan pentingnya partisipasi politik, dan bagaimana peran yang dapat mereka ambil dalam area tersebut.

Apalagi, survey awal yang dilakukan tim pengabdian melalui wawancara sekilas dengan para pemuda sekitar mendapati fenomena bahwa para pemuda di Kelurahan Mandan memang cenderung abai dengan aneka fenomena politik. Politik dianggap sebagai alat para pemangku kepentingan untuk melancarkan kepentingan 
pribadinya, sehingga politik jadi hal yang dianggap "negatif". Mereka berpikiran bahwa dunia politik bukanlah dunia untuk orang-orang Kelurahan. Apapun yang terjadi dalam dunia politik dianggap tidak berpengaruh terhadap kehidupan mereka. Cukuplah bagi mereka memikirkan cara mendapatkan uang dengan cara kerja keras.

\section{Realisasi Pelaksanaan}

Program pengabdian kepada masyarakat yang mengusung tentang "Upaya pendidikan politik dalam rangka penguatan partisipasi politik pemuda di Indonesia" difokuskan pada lokasi mitra, yakni di Kelurahan Mandan, Kecamatan Mandan, Kabupaten Sukoharjo. Program pengabdian dilaksanakan dalam rangkaian jadwal kegiatan selama empat bulan, dimulai dari bulan Januari hingga April 2019. Rangkaian program dimulai dari penjajagan terhadap kelompok sasaran pada bulan Januari, diikuti dengan persiapan materi yang akan disampaikan dalam sebuah sosialisasi. Adapun sosialisasi telah terselenggara oleh tim pengabdian dengan baik dan lancar, selama satu hari, yakni pada :

Hari/ tanggal : Sabtu, 21 April 2019 pukul 09.00 - 13.00

Lokasi : Balai Kelurahan Mandan, Kecamatan Mandan, Kabupaten Sukoharjo.

Peserta $\quad$ : Anggota Karang Taruna Kelurahan Mandan, (34 orang)

Kegiatan : Sosialisasi dan diskusi aktif.

Sebelum sosialisasi berlangsung, dilakukan penjajagan terhadap kelompok sasaran. Penjajagan kelompok sasaran adalah rangkaian penting dan tak terpisahkan dalam program pengabdian kepada masyarakat yang dilakukan. Sebab, penjajagan menjadi tolok ukur utama dari sukses tidaknya program pengabdian yang dilakukan. Tolok ukur tersebut dilihat dari apakah program pengabdian yang telah dilakukan dapat memberikan pengaruh atau imbas sesuai yang diharapkan. Selain itu, penjajagan juga memastikan bahwa konten atau materi yang akan disampaikan serta metode yang digunakan sesuai dengan kebutuhan kelompok sasaran. Dengan demikian, program pengabdian akan berlangsung efektif dan tepat sasaran, sesuai tujuan dari rumusan masalah yang telah dipilih untuk diselesaikan. 
Selanjutnya, setelah penjajagan selesai dilakukan, tim pengabdian terus berkoordinasi dengan perwakilan dari tim kelompok sasaran dalam penyusunan materi atau konten. Koordinasi dilakukan guna memastikan bahwa materi dan metode yang telah disiapkan oleh tim pengabdian benar-benar sesuai dengan kebutuhan kelompok sasaran. Agar lebih efektif dan efisien, kegiatan sosialisasi dilaksanakan dalam jangka waktu satu hari. Waktu satu hari dianggap cukup guna menyampaikan sosialisasi materi serta dilanjutkan dengan kegiatan diskusi aktif. Yang terpenting, tim pengabdian berupaya memastikan rangkaian kegiatan sosialisasi memuat konten yang tepat dan disampaikan dengan cara yang sesuai dengan kebutuhan dan karakter kelompok sasaran.

\section{METODE PELAKSANAAN}

Program pengabdian kepada masyarakat dilakukan guna menjawab berbagai permasalahan sosial di seputar PT. Adapun metode pelaksanaannya perlu melalui pertimbangan matang untuk menyesuaikan dengan kebutuhan mitra sekaligus agar efektif dalam menjawab permasalahan. Metode pelaksanaan yang dilakukan sebagai solusi yang ditawarkan untuk mengatasi permasalahan yang sedang dihadapi, yakni terkait bagaimana upaya pendidikan politik dalam rangka penguatan partisipasi politik pemuda di Indonesia adalah sebagai berikut:

\section{Penjajagan Kelompok Sasaran.}

Para peserta pengabdian dipilih sesuai target pengabdian, yakni para pemuda di Kabupaten Sukoharjo, tepatnya di Karang Taruna Mandan. Para pemuda dipilih secara keseluruhan dari anggota karang taruna, baik yang sudah memiliki kesadaran untuk terlibat dalam partisipasi politik maupun yang belum. Pemilihan ini diharapkan mampu tepat sasaran pada akhirnya para pemuda dengan kesadaran politik ini dapat terus menyebarkan dan memperluas pengetahuannya kepada orang-orang di sekitarnya. Dengan memberikan gambaran mengenai pentingnya pendidikan politik para pemuda diharap mampu menjadi agen pembangunan bagi bangsa secara positif. 
Penjajagan kelompok sasaran menjadi rangkaian awal dari pelaksanaan program pengabdian ini. Dalam penjajagan, tim pengabdian berupaya untuk memetakan karakteristik para pemuda dan mengetahui tingkat pemahaman politik serta partisipasi politik para pemuda sasaran. Cara ini dapat memberikan gambaran terkait kebutuhan materi kelompok sasaran. Dengan demikian, sajian materi yang diberikan bisa sesuai dengan sasaran atau efektif.

\section{Sosialisasi dan motivasi}

Kegiatan pengabdian pada masyarakat dengan skema pendidikan politik bagi para pemuda ini akan dilangsungkan dalam pertemuan tatap muka secara bersama-sama. Tatap muka dilakukan setelah selesai dilakukan penjajagan dan penyusunan materi yang disesuaikan dengan kelompok sasaran. Secara umum, pendidikan politik disampaikan melalui teknik sosialisasi dan diskusi aktif. Para pemuda akan dikumpulkan dan diberikan informasi dan wawasan terkait pendidikan politik.

Selanjutnya, para peserta juga akan diberikan arahan, pembekalan dan pembimbingan terkait langkah konkrit yang dapat mereka lakukan sebagai bentuk partisipasi politik. Tak hanya itu, agar para pemuda bersedia secara sadar dan konsisten untuk terlibat dalam partisipasi politik yang positif, mereka juga akan diberikan motivasi. Motivasi dimaksudkan untuk mengarahkan para pemuda pada minat terhadap kegiatan politik dan menganggap bahwa politik adalah skema positif demi mendukung kemajuan bangsa.

\section{PEMBAHASAN}

Memberikan bekal pendidikan politik bagi para pemuda generasi penerus bangsa adalah hal penting. Pendidikan politik yang baik akan menjadi pondasi yang baik pula bagi para pemuda untuk mengambil tindakan yang tepat dalam kegiatan berbangsa dan bernegara. Menyadari pentingnya hal tersebut, tim pengabdian 
berupaya untuk mengambil peran dalam memberikan pendidikan politik bagi para pemuda di Kelurahan Mandan, Kabupaten Sukoharjo.

Tim pengabdian berupaya menyampaikan materi pendidikan politik yang mencakup berbagai urusan terkait hak dan kewajiban politik individu sebagai warna negara. Secara rinci, materi yang disampaikan dalam kegiatan sosialisasi tersebut, terdiri dari (1) pengenalan politik; (2) pentingnya partisipasi politk; (3) tindakan ideal pemuda dalam berpartisipasi politik.

Dengan mengetahui hal tersebut, kelompok sasaran akan lebih memahami tentang pendidikan politik. Sebab, sesungguhnya budaya partisipasi politik aktif bagi masyarakat adalah hal penting. Partisipasi politik aktif akan lebih penting dalam sebuah negara demokrasi seperti Indonesia.

Masyarakat perlu memiliki bekal yang cukup terkait informasi, wawasan dan keterampilan politik. Pada akhirnya, bekal yang telah diterima oleh para pemuda di kelompok sasaran dapat membuat mereka lebih bersikap dan berpikir kritis serta lebih terarah dalam tindakan politiknya. Dengan bekal pendidikan politik yang mencukupi, masyarakat dapat menentukan tindakan politiknya secara lebih mandiri, dapat arti mereka tidak mudah terpengaruh terhadap orientasi kepentingan pihak lain.

Penjajagan yang telah dilakukan terhadap para pemuda di kelompok sasaran menunjukkan bahwa di awal sebelum dilakukan sosialisasi, mereka terbilang abai dalam permasalahan politik. Hal ini dilihat dari minimnya pengetahuan terkait partisipasi politik aktif. Para pemuda mengaku bahwa mereka lebih suka abai terhadap politik. Ini lantaran persepsi masyarakat umum terhadap politik yang memiliki stigma negatif.

Masyarakat umum yang merasa skeptis terhadap dunia perpolitikan Indonesia seringkali menularkan persepsi negatif pula pada para pemuda. Kondisi ini tentu tidak ideal bagi tumbuh kembang perpolitikan dalam bangsa yang menganut asas demokrasi. Demokrasi membutuhkan partisipasi politik aktif dari masyarakat secara luas. Semakin aktif tingkat partisipasi politiknya, semakin tinggi indeks demokrasinya.

Para pemuda menjadi tumpuan penting dalam mendorong partisipasi politik aktif ini. Ketika para pemuda mampu memberikan kontribusi politik dalam demokrasi, diharapkan semangat ini dapat ikut menyebar. Selain itu, kelak para pemuda juga 
akan terus menyadari pentingnya keterlibatan masyarakat dalam menjalankan fungsi kontrol dalam politik demokrasi. Namun, jika para pemuda telah dijejali dengan aneka informasi skeptis atau negatif terkait politik, hal ini dapat berpengaruh terhadap buruknya penilaian politik mereka di masa mendatang. Para pemuda Kelurahan Mandan juga merupakan agen penerus bangsa yang penting untuk diberi informasi tentang partisipasi politik.

Meski awalnya para pemuda sedikit skeptis dengan dunia politik, setelah diberi sosialisasi, mereka menunjukkan antusias dan pandangan positif terhadap politik. Hal ini diketahui dari diskusi aktif yang terjadi setelah sosialisasi. Mereka mendapat gambaran penting tentang bagaimana seharusnya peran pemuda dalam negara demokrasi. Mereka pun menyadari bahwa dalam politik modern, partisipasi politik pemuda memegang peran sentral dalam kontrol politik. Keterlibatan para pemuda dapat mendorong percepatan kemajuan bangsa. Mereka juga diberi bekal tentang hal-hal apa saja yang dapat mereka lakukan sebagai bentuk partisipasi politik.

\section{CONCLUSION}

Bagi suatu negara demokrasi, partisipasi politik aktif dari masyarakat merupakan hal penting. Sebagai bentuk kontribusi UNISRI dalam pembangunan politik Indonesia, tim pengabdian menjalankan program pengabdian berupa pendidikan politik dalam rangka penguatan partisipasi politik pemuda. Kegiatan dilakukan di Kelurahan Mandan, Kabupaten Sukoharjo. Pengabdian bertujuan untuk memberikan pendidikan politik yang sesuai dengan kebutuhan para kelompok sasaran, demi mendorong partisipasi politik aktif mereka secara positif.

Partisipasi politik yang baik membutuhkan pemahaman politik yang baik pula. Informasi yang tepat akan berpengaruh pada respon yang diberikan dan tindakan politik yang diambil. Dalam kegiatan pengabdian yang diawali dengan penjajagan ini diketahui bahwa awalnya para pemuda Kelurahan Mandan tidak terlalu peduli dengan politik, bahkan cenderung menilai negatif terhadap politik. Hal ini lantaran pemahaman yang berkembang di daerah tersebut yang biasa abai dengan kegiatan perpolitikan. 
Tim pengabdian melakukan kegiatan sosialisasi dan memberikan informasi secara wawasan politik secara ringan. Mereka diajak berdiskusi tentang politik dan ditunjukkan betapa pentingnya kontribusi mereka terhadap politik. Kontribusi para pemuda bagi Indonesia yang merupakan negara demokrasi selalu dinanti agar demokrasi dapat berjalan sebagaimana mestinya. Partisipasi politik aktif pemuda dapat memastikan bahwa demokrasi yang berlangsung merupakan hasil aspirasi masyarakat.

Saran yang diberikan tim dalam kegiatan pengabdian serupa adalah perlunya diselenggarakan pendidikan politik secara lebih luas lagi. Pendidikan politik bagi para pemuda sangat penting untuk membangun pemikiran politik yang matang. Para pemuda diharapkan mampu mengambil sikap dan tindakan politik secara tepat dalam rangka merespon dinamika politik yang berlangsung.

\section{DAFTAR PUSTAKA}

Bappenas dan Depdagri. 2002. Pedoman Penguatan Pengamanan Program Pembangunan Daerah.

Kantaprawira, Rusadi. 2004. Sistem Politik Indonesia, Suatu Model Pengantar, Edisi Revisi, Sinar baru Algensindo, Bandung.

Luengo, Oscar Garcia. 2006. E-Activism New Media and Political Participation London : in Erope.

Prabowo. 2000. Pembelajaran Fisika Dengan Pendekatan Terpadu Dalam Menghadapi Perkembangan IPTEK Millenium III. Jakarta: Himpunan Fisika Indonesia 2000. 